BGPE Discussion Paper

No. 87

\title{
The Economics of Regional Demarcation in Banking
}

\section{Simone Raab Peter Welzel}

\section{January 2010}




\title{
THE ECONOMICS OF REGIONAL DEMARCATION IN BANKING
}

\author{
SIMONE RAAB
}

Peter Welzel

FACULTY Of BUSINESS AdMinistration ANd ECONOMICS

UNIVERSITY OF AUGSBURG

VERSION OF JANUARY 18, 2010

\begin{abstract}
Cooperation among savings and cooperative banks was criticized by the European Commission because of potentially anti-competitive effects. In an industrial economics model of banks taking deposits and giving loans we look at regional demarcation as one of such cooperative practices. There are two adjacent markets with one savings or cooperative bank being focused on each one and one private commercial bank serving both. We find that abolishing regional demarcation indeed increases total loan volume. Savings or cooperative banks always improve market performance and do better without regional demarcation which shields the private commercial bank from aggressive competition by these banks.
\end{abstract}

Keywords: banking, competition, cooperation, non-profit firms

JEL classification: G21, L41, L44, L33, L13 


\title{
THE ECONOMics of Regional DEMARCATION IN BANKING
}

\author{
Simone RaAB ${ }^{1}$, Peter Welzel ${ }^{2}$ \\ UNIVERSITY OF AUGSBURG
}

VERSION OF JANUARY 18, 2010

\section{Introduction}

Regional demarcation in the banking industry recently gained considerable interest following a communication on retail banking issued by the European Commission. In its final report the Commission stated its qualms about a lack of effective competition in EU retail banking markets and pointed out the traditionally close cooperation within the sectors of savings banks and cooperative banks which play an important role in member states like Germany, France and Austria (European Commission, 2007). While the Commission acknowledged that cooperation can result in economic and consumer benefits as long as the banks involved are small and do not jointly possess a significant market share, it indicated that a more serious analysis of the competitive effects of cooperation would be appropriate when the combined market position of the cooperating banks threatens to limit competition. Already in October 2006 the Commission had asked the umbrella organization of the savings banks and the cooperative banks to explain the legal, organizational and economic foundations of their respective sectors in a questionnaire (Scheerer, 2007).

In its accompanying staff working paper the Commission's Directorate-General for Competition pointed out that the presence of savings and cooperative banks leads to relatively low concentration ratios in the German banking industry on the one hand, but may damage competition through the regional market sharing and other cooperative arrangements among these banks on the other (European Commission, Directorate-General for Competition, 2007, pp. 19, 39). In the three-pillar structure of Germany's banking industry, the savings banks and cooperative banks in principle refrain from competing among each other in their lending business and focus on competition with banks from the other two pillars. ${ }^{3}$ Whereas representatives from the groups of savings banks and

\footnotetext{
${ }^{1}$ Email: simone.raab@wiwi.uni-augsburg.de.

${ }^{2}$ Corresponding author. Email: peter.welzel@wiwi.uni-augsburg.de. Both authors are grateful to the participants and discussants at the $5^{\text {th }}$ European Banking Symposium in Maastricht, the $10^{\text {th }}$ GEABA Symposium in Vallendar, and the $8^{\text {th }}$ Workshop on Economic and Business Policy in Sion for their helpful comments and suggestions. We especially thank Thomas Gehrig for his very thoughtful comments. The usual disclaimer applies.

${ }^{3}$ See the staff working paper for additional information on the details, including the legal status, of the regional principle in Germany and other member states (European Commission, Directorate-General for Competition, 2007, pp. 42, 44-45).
} 
cooperative banks claim that this rule contributes to more effective competition, the Commission voiced its concerns, indicating that regional demarcation may in fact lower competition intensity. Regional demarcation was explicitly included in the questionnaire mentioned above.

Reactions from parties concerned came immediately (Drost, Köhler, \& Scheerer, 2007): Whereas the head of Association of German Banks, the head organization of the first pillar comprising the private commercial banks, lauded the Commission and its questioning of regional demarcation, the heads of the savings banks' and cooperative banks' umbrella organizations insisted on the pro-competitive effects of the banks they represent. Even the European Parliament dealt with the issue. On June 5, 2008, it almost unanimously adopted a resolution based on a report by the Italian MPE Pittella, supporting the Commission but also regretting its lack of taking "sufficient account of the specificities of the strictly regulated banking sector and the importance of culture, habits and languages in consumer choices and protection for financial products" (European Parliament, 2008). As for cooperation between banks, the European Parliament emphasized the positive role of all banks for the local economy and for the endogenous potential of regions. In the cooperative banking sector this resolution was interpreted as a total rout for the Commission (Profil, 2008).

Since summer 2008 the excitement about the Commission's report has subsided. The banking crisis and its dramatic consequences for the real economy completely dominate public perception. In fact, savings banks and cooperative banks appear as pillars of stability these days, providing liquidity to local and regional economies. Their position has been considerably strengthened both economically and politically. This is not the time to criticize them or question their conduct. Nevertheless, the basic questions raised by the European Commission deserve further attention: Does cooperation among savings banks and cooperative banks enhance or restrict effective competition in the banking industry? And, more specifically, is regional demarcation in the savings and cooperative banking sectors a device that furthers or hinders competition among banks?

In this paper we focus on the latter question. At first sight, conventional wisdom from microeconomics strongly suggests that restricting the intensity of competition by keeping competitors out of a market by means of regional demarcation will lead to a deterioration of market performance. However, savings banks and cooperative banks are firms with atypical, non-standard objective functions. They are obliged to pursue other objectives but profit maximization. Once this stylized fact is taken into account, the answer to the question of the impact of regional demarcation is open again. Using the industrial economics approach to banking (cf. Freixas \& Rochet, 2007, chpt. 3) we want to shed some light on the issue. We consider two adjacent bank duopolies with one private commercial bank operating in both markets and one savings or cooperative bank present in each one separately. We compare the initial situation with regional demarcation to the one without in which each of the two savings or cooperative banks competes in both markets. Banks optimally choose loan and deposit volumes. As in Germany regional demarcation applies mainly to lending activities, 
we explicitly present our results only for the banks' loan business. For the sake of completeness we also briefly mention consequences for the deposit markets.

The remainder of the paper is structured as follows: In section 2 we briefly present the related literature. Section 3 contains our model and the derivation of our results. Extensions will be examined in section 4 . Section 5 sums up.

\section{REVIEW OF THE LITERATURE}

Private commercial banks from the first pillar of the German banking industry tend to argue that regional demarcation creates a disadvantage for them. Standard microeconomic thinking suggests disadvantages on the industry level at first sight. When, say, a savings bank in one region refrains from competing for customers in another region because of the fact that there is a savings bank present in this market, the intensity of oligopolistic competition in this other market is lower than it could be which results in a welfare loss. And the same happens in the home region of the savings bank considered which does not face competition from its counterpart located in the other region. Furthermore, the principle of regional demarcation restricts savings and cooperative banks in their choice of partners in merger projects. They cannot pick the most suitable partner, creating the highest efficiency gain possible, but are limited to partners from adjacent regions. This is particularly important for Germany where during the last decades hundreds of mergers among savings banks and among cooperative banks took place. For cooperative banks Lang and Welzel found evidence for the potential efficiency gains forgone in merger projects due to the impossibility to choose the best partner (Lang \& Welzel, 1999).

In this paper we will not look at the dynamic consequences of regional demarcation in the context of bank mergers. We focus on a given number of banks and examine the consequences of the fact that some banks refrain from competing with each other. Regional demarcation looks like a (legal) region cartel with the well-known consequences for market performance in a standard oligopoly framework. However, in competition theory models of workable and effective competition also point to potentially welfare enhancing effects of reducing competition among smaller firms when they face a large firm. But given the quite remarkable market shares which savings and cooperative banks hold in many regional markets, it is not convincing to defend regional demarcation this way. In Germany, for example, regional demarcation rules for savings and cooperative banks are not based on $\S 3$ of the German Act against Restraints of Competition which permits cartels of small and medium-sized firms. In our opinion, the non-standard objective functions of both savings and cooperative banks constitute a more interesting issue, raising second thoughts whether the conventional wisdom from oligopoly theory applies for regional demarcation.

Somehow related to our problem is the literature on foreign bank entry after a liberalization of the banking market. Most articles investigate the entry of a new bank either via acquisition of a domestic bank or via greenfield investment and conclude that competition 
intensity increases, prices decrease and access to financial products improves. Whether this has welfare-enhancing effects is by no means clear-cut, because the related decrease in banks' profits may mitigate their incentives to make necessary investments for example in a profitable screening technology (cf. for example Lehner \& Schnitzer, 2008). Banks in such a market entry setting probably differ in their information about customers. For example in Dell'Ariccia \& Marquez (2004) domestic banks enjoy an informational advantage and thus capture their borrowers. Facing an increase in competition, domestic banks then concentrate on their captive sectors where they serve both, good and risky customers, while foreign banks engage in sectors with less information asymmetry and serve good customers offering smaller interest rates.

There exist a few papers which deal with regional demarcation and the way savings and cooperative banks compete. Hempell (2002) investigated competition in German banking empirically and found less competitive behavior for cooperative banks and savings banks compared to private commercial banks (excluding the very largest banks). For an explanation she pointed to regional demarcation which excludes competition within two of the three pillars of the industry (Hempell, 2002, pp. 32-33). Hakenes \& Schnabel (2007) confirm the proposition that regional demarcation restricts competition. But the authors show that this limitation may also have positive effects. Banks with a regional focus are able to establish closer relationships with their customers, creating benefits e.g. from customer loyalty, a homogeneous mentality, identification with the region and its economy, and so on. All this can be used to generate and extract information, especially soft information, from a bank's customers. As such information is crucial for loan supply to small and medium sized firms or private customers with little collateral, regionally oriented banks may be able to serve clients a bank operating nationally would refuse to serve because of problems of asymmetric information. On balance, the net effect of regional demarcation on social welfare is ambiguous (Hakenes \& Schnabel, 2007).

In a previous article, Hakenes and Schnabel showed that banks focused on a region are able to increase social welfare at least of that region, when they invest local funds in local projects (Hakenes \& Schnabel, 2006). The authors argue that such banks can help solve the problem of capital drain from poorer to richer regions offering better interest rates for depositors. In accordance with their statutes savings banks can implicitly subsidize local loans by not pursuing profit maximization. Analogously, cooperative banks following the principles of cooperative banking grant privileged access to funds and loans for their members. This beneficial role of savings and cooperative banks is only viable under the condition of credible regional demarcation.

The ongoing discussion about the reformation of the German savings bank sector reflects these issues. Regional demarcation is seen as fostering access to financial services and economic growth in all regions, thereby enhancing social welfare. Private commercial banks with their focus on profit maximization cannot deliver this result because they concentrate on prospering regions. By partially eliminating competition among banks from different 
regions competitive pressure between regions is reduced which helps weaker regions. However, the price to be paid is a sub-optimal capital allocation between regions. Savings banks are excluded from possibly beneficial capital transactions outside their home regions and are restricted in their growth possibilities (Müller, 2005).

Regional demarcation is a phenomenon which can be found in the savings and cooperative banking sectors of several European countries. However, in some places the process of privatizing savings banks went hand in hand with the abolition of regional demarcation (for example in Italy 1990, Austria 1979, and Spain 1988). Other countries like France maintained regional demarcation when their savings banks were converted into cooperative banks (cf. Brunner et al., 2004, pp. 39-41, Hakenes \& Schnabel, 2006, p. 4). In Italy competition in the banking industry increased following the abolition of regional restrictions, but banking activities had been much more limited by Italian regulation before than they are, for example, by regional demarcation in Germany (cf. Carletti, Hakenes, \& Schnabel, 2005). Carletti et al. note that competition could possibly be intensified by abolishing the regional demarcation principle in Germany. However, they remain skeptical towards the possibility of transfering Italian-style reforms and especially their positive consequences to the German banking market because Germany's initial situation is very different (cf. Carletti, Hakenes, \& Schnabel, 2005, p. 47 f).

Brunner et al. find empirical evidence that competition intensity in the German banking sector is comparable to the one in Italy or Spain, where regional demarcation was abolished, and more intense than in France where it still exists (Brunner, Decressin, Hardy, \& Kudela, 2004 , p. 23). The question is whether getting rid of the regional principle intensifies competition (and which banks suffer or benefit from this change) or whether the procompetitive effects are somehow compensated. Following reforms affecting savings and cooperative banks, observers found evidence of higher profitability of banks (Brunner, Decressin, Hardy, \& Kudela, 2004, pp. 39-42) and, for Italy, Spain and France, of an increase in market power (Engerer \& Schrooten, 2004, p. 3) which may be the result of mergers following the reforms.

From the US market we have evidence that some banking products like deposits and small business lending are "local in nature" (Hannan \& Prager, 2004, p. 1890). As a consequence, some banks are operating only in one local area (called "single-market banks"). However, multimarket banks operating in several local areas came into existence in recent years, especially after deregulation of regional restrictions. Hannan and Prager show theoretically and empirically that multimarket banks which offer the same interest rate in all regions on average offer a lower payment for deposits than regional banks, inducing these banks to also reduce their deposit rates. The authors mention more market power due to their larger operation area, less efficiency because of diseconomies of scale or scope, and better access to alternative funds as reasons for the lower interest on deposits offered by multimarket banks. Transferred to our context this indicates that banks with a regional focus improve 
their customers' economic situation compared to banks with nationwide operations. This supplements our findings.

Another critical point of integration is analyzed by Gehrig who shows that opening the banking market to foreign competitors involves also costs (Gehrig, 1998). Although integration may intensify competition and thereby reduce banks' oligopoly rents, it may also reduce banks' incentives to screen their borrowers' projects which leads to more risky loan portfolios. Then, necessary risk premia may even outweigh a decline in loan rates due to fierce competition. In this case a foreclosure of regional competition - for example through maintaining regional demarcation - is beneficial. Gehrig identifies especially members of the European Union as candidates for such costs of integration.

Having reviewed the literature, we now turn to our research question. In a standard oligopoly framework we want to shed some light on the impact of regional demarcation on competition in banking. We are interested in the pro- or anti-competitive effects of preventing savings banks from competing with savings banks and cooperative banks from competing with cooperative banks. Specific attention is paid to the fact that savings and cooperative banks pursue other objectives than private commercial banks. We focus on the market structure effects and their consequences and consciously leave out informational aspects which can add to the effects we identify.

\section{MODEL}

\subsection{BASIC SETUP}

Consider two regional banking markets, $i=1,2$, adjacent to each other. There are a number $n_{0}$ of (large) private commercial banks operating in both markets simultaneously. In addition, there are $n_{s i}$ savings banks and $n_{c i}$ cooperative banks in each market $i$. According to the logic of regional demarcation, $n_{s i}$ and $n_{c i}$ can take only the values of 0 and 1 , i.e., there can be no more than one savings bank and one cooperative bank in a market. Furthermore, the regional principle requires a savings bank and a cooperative bank in market $i$ to serve loan demand only from this market. Customers from the other market $j$, $j \in\{1,2\}, j \neq i$, showing up at the bank will not be served.

To focus on the most basic setup, assume $n_{0}=1, n_{c i}=1$ and $n_{s i}=0$, i.e., we consider one private commercial bank operating in both markets, called bank 0 , and one savings or cooperative bank in each market, called bank $c(1)$ in market 1 and $c(2)$ in market 2 , operating only in its home market. In total we have two adjacent duopolies with bank 0 competing in both markets: 


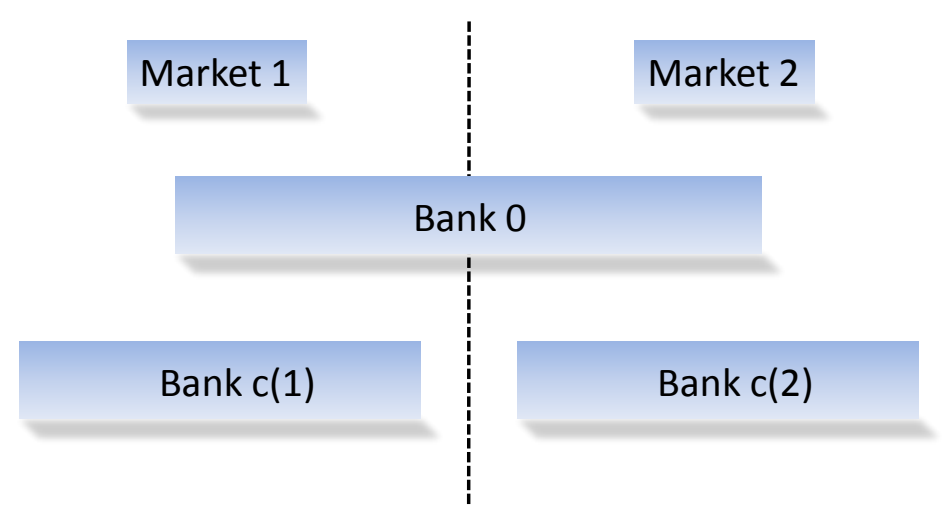

FIGURE 1: BANKING MARKETS UNDER REGIONAL DEMARCATION

The fact that in Figure 1 we represent bank 0 in market $i$ smaller than bank $c(i)$ reflects the empirical observation that savings banks and cooperative banks in regional markets quite often have similar or even larger market shares than private commercial banks which operate in many regions simultaneously. For this reason we do not model bank 0 in market $i$ as a large or dominant bank.

Whenever there is no need to explicitly distinguish between the two savings or cooperative banks, as is the case when we look at only one market under regional demarcation, we simplify our notation and use the symbol $c$ instead of $c(1)$ or $c(2)$. Let $k \in\{0, c\}$ then denote the two banks present in a market.

We use the intermediation approach from the industrial economics of banking (cf. Sealey \& Lindley, 1977) which dominates both theoretical and empirical analyses and consider banks as firms receiving deposits and giving loans. Total loan volume in market $i$ is $L_{i}=L_{i}^{0}+L_{i}^{c}$, i.e., it consists of the loans $L_{i}^{0}$ originated by bank 0 and those loans $L_{i}^{c}$ granted by bank $c$ to customers of market $i$. Each bank charges its borrowers an interest rate $r_{L}^{k}$. For simplicity we assume that loans do not bear any project risk and therefore banks do not have to care about creditworthiness of their customers. In fact, a change in competition due to the abolition of regional demarcation influences a bank's loan portfolio and the related risk situation (cf. Gehrig, 1998). Depending on the ability of different bank types to extract information about their risky customers this may hurt banks differently. It is not obvious if regional acting savings and cooperative banks are able to realize informational advantages or if they suffer more from an increase in risk than their commercial competitors. We further discuss this point in our conclusion.

In the deposit business we have in market $i D_{i}=D_{i}^{0}+D_{i}^{c}$. The corresponding interest rate each bank has to pay to its depositors is denoted by $r_{D}^{k}$. Omitting bank- and markets-specific subscripts and superscripts, a bank's profit function is

$$
\pi=r_{L} L-r_{D} D+r M-C(L, D)
$$


where $M$ is the bank's (positive or negative) position in the interbank market, earning or paying an exogenously given market interest rate $r$, and $C(L, D)$ is the cost function, capturing the operational costs of the bank. We assume the usual properties of positive first derivatives and of second derivatives to ensure existence of solutions to the banks' maximization problems. As for the cross derivatives we make no specific assumption, but note via these cross derivatives our cost function may include a (sufficient) condition for economies or diseconomies of scope between the bank's loan business and its deposit business. Since we are not interested in regulatory issues of the Basel 1 and Basel 2 type, we can neglect the bank's equity without loss of generality. Loans are financed with funds from deposits and perhaps the interbank market. The bank's stylized balance sheet is then given by

$$
D=\alpha D+L+M
$$

where $\alpha D$ is the contribution to deposit insurance and the minimum reserve paid to the central bank. Substituting this budget condition (2) into (1) yields the simplified profit function

$$
\pi=\left(r_{L}-r\right) L+\left(r(1-\alpha)-r_{D}\right) D-C(L, D)
$$

Interest margins in the loan business and the deposit business, loan and deposit volumes, and operational costs determine a bank's profit.

Since we analyze oligopolistic markets, the choice of decision variables - prices, i.e., interest rates, or quantities, i.e., loan and deposit volumes - matters for our results. Practitioners in the banking industry would probably claim that they set interest rates for loans and deposits in order to maximize their objective functions. However, we follow the majority in the industrial economics literature on banking and use quantities as decision variables. The wellknown reasoning by Kreps and Scheinkman that capacity choice followed by price competition is logically equivalent to quantity competition further motivates this procedure (Kreps \& Scheinkman, 1983). In the case of banks we should note that capacity choice not only includes building or renting office space and hiring and training staff, but also collecting a certain amount of equity capital. Once equity is given, it constitutes a capacity limit in the loan business under Basel-type banking regulation. Kirstein and Schliephage have shown only recently that if equity restricts lending activities this induces banks to reduce the intensity of price competition. They obtain Cournot equilibria as long as raising equity is sufficiently costly (cf. Kirstein \& Schliephage, 2009). We therefore feel vindicated in our view that it makes sense to assume that banks choose their optimal loan and deposit volumes in order to maximize their objective functions.

Turning to objective functions, let us first state that private commercial banks can safely be assumed to be interested in profit maximization only, using the profit function defined in (3). However, the banks belonging to the other pillars of the banking system which we label by $c$ 
or $c(i)$ in our model pursue other objectives than pure profit maximization. Savings banks are obliged to improve social welfare, for example by providing access to affordable loans and deposits. Cooperative banks have to improve the economic situation of their members. In its staff working paper the Commission acknowledged this specific role of savings and cooperative banks: "Large shares of retail banking activity in Member States such as Austria, Germany, France, Italy and Spain are undertaken by cooperative banks and savings banks. Many of these banks have social objectives, including widening access to finance for consumers and SMEs, which are likely to create a different set of profit incentives to shareholder-owned private banks" (European Commission, Directorate-General for Competition, 2007, p. 24).

There exist different ways to model non-profit objectives. Examples can be found in the literature on mixed oligopolies which analyzes competition between profit maximizing and non-profit maximizing (public) firms (Merrill \& Schneider, 1966, Rees, 1984, Cremer, Marchand, \& Thisse, 1989, De Fraja \& Delbono, 1989). Often such non-profit firms are modeled as focusing on social welfare consisting of consumer and producer surplus (cf. Bárcena-Ruiz, 2007, pp. 265-266) or as taking at least consumer surplus into account (cf. Welzel, 1996). In the area of banking Smith considers a credit union which maximizes service to its members subject to a zero-profit constraint, where service is measured by the interest rate spread credit union members gain by banking at the credit union instead of going to a private commercial bank (Smith, 1984). Barros and Modesto model a public bank maximizing apart from operating earnings its volume of loans and deposits, valued at their opportunity costs (Barros \& Modesto, 1999). Pursuing this objective function will increase the supply of loans and the demand for deposits. The same holds true for an approach suggested by Neumann and coauthors (Neumann \& Reichel, 2006; Neumann, Reichel, \& Weigand, 2008). They assume that non-profit banks determine their output such that their operating earnings equal zero.

The view that savings and cooperative banks produce higher loan and deposit volumes than private commercial banks is in line with Lakdawalla and Philipson's theory of nonprofit firms which they treat as firms willing to forego profits in exchange for higher output (Lakdawalla \& Philipson, 2006). We therefore model these banks as considering their earnings on the one hand and output levels on the other. Since our prime interest is in the joint effects of regional demarcation and the existence of banks (also) pursuing non-profit objectives, we do not care about the detailed differences between a savings bank and a cooperative bank. In fact, we treat them as identical.

This leads us to modify the approach of Barros and Modesto (1999) and assume that those banks labeled by $c$ and $c(i)$ which could be either savings or cooperative banks recognize in their objective functions the volume of loans and of deposits, weighted with their opportunity costs. Omitting bank- and markets-specific subscripts and superscripts the profit function savings banks and cooperative banks maximize is 


$$
\pi=\left(r_{L}-r\right) L+\left(r(1-\alpha)-r_{D}\right) D+\theta_{L} r L+\theta_{D} r(1-\alpha) D-C(L, D) .
$$

We suggest that in our context, the parameters $\theta_{L}$ and $\theta_{D}$ can be interpreted as the additional value a savings or cooperative bank realizes when attending to its social duty and providing access to loans and deposits. ${ }^{4}$ To simplify the terminology we from now on speak of a cooperative bank when addressing a bank $c$ or $c(i)$.

\subsection{Equilibrium under Regional Demarcation}

In this first step we analyze the two markets separately. The private commercial bank 0 is operating in both markets, while the activities of banks $c(i)$ and $c(j)$ are restricted by regional demarcation to either market $i$ or market $j$. In each market competition is then characterized by a mixed duopoly. We assume that both cooperative banks are identical and restrict our analysis to market $i$.

Inverse demand functions for loans and inverse supply functions for deposits in market $i$ are given by

$$
\begin{array}{lll}
\left(r_{L}^{0}\right)_{i}=a-L_{i}^{0}-b\left(L_{i}^{c(i)}+L_{i}^{c(j)}\right) & \text { and } & \left(r_{L}^{c}\right)_{i}=a-\left(L_{i}^{c(i)}+L_{i}^{c(j)}\right)-b L_{i}^{0} \\
\left(r_{D}^{0}\right)_{i}=e+D_{i}^{0}+f\left(D_{i}^{c(i)}+D_{i}^{c(j)}\right) & \text { and } & \left(r_{D}^{c}\right)_{i}=e+\left(D_{i}^{c(i)}+D_{i}^{c(j)}\right)+f D_{i}^{0}
\end{array}
$$

with $b, f \in[0 ; 1]$ representing the degree of product differentiation. If $b, f=1$, loans or deposits offered by a private commercial bank do not differ from those offered by a cooperative bank. With $b, f<1$, customers value banking products differently, depending on whether they are sold by bank 0 or by bank $c(i)$. Differences in customer valuation can arise e.g. from customer proximity, emotional attachment or loyalty to one bank type or another, or a different level of service and advice surrounding the product. Note that customers do not distinguish between products offered by the cooperative banks. This is a simplifying assumption reflecting the fact that customers primarily value the cooperative idea. If customers had a personal relationship to "their" cooperative bank, one would have to introduce different weights for different banks even within the cooperative sector. For later use we include loan and deposit volumes of the cooperative bank $c(j)$ in market $i$ in (5). At this stage the regional demarcation principle implies that these values have to be set equal to zero in the decision problems. Later, when we look at the equilibrium without regional demarcation, this restriction will be dropped.

Bank 0's maximization problem is

\footnotetext{
${ }^{4}$ In Barros and Modesto (1999), the parameters $\theta_{L}$ and $\theta_{D}$ represent weights for the revenues from loans and deposits which are chosen by government for regulatory reasons.
} 


$$
\begin{array}{ll}
\max _{L, D} \pi^{0} & =\left(\left(r_{L}^{0}\right)_{i}-r\right) L_{i}^{0}+\left(r(1-\alpha)-\left(r_{D}^{0}\right)_{i}\right) D_{i}^{0} \\
& +\left(\left(r_{L}^{0}\right)_{j}-r\right) L_{j}^{0}+\left(r(1-\alpha)-\left(r_{D}^{0}\right)_{j}\right) D_{j}^{0}-C\left(L_{i}^{0}, L_{j}^{0}, D_{i}^{0}, D_{j}^{0}\right) \\
\text { s.t. } & L_{i}^{c(j)}=L_{j}^{c(i)}=0, D_{i}^{c(j)}=D_{j}^{c(i)}=0
\end{array}
$$

The private commercial bank maximizes its combined profit from both markets served. The constraints represent the principle of regional demarcation. Using (4) we get for the cooperative bank in market $i$

$$
\begin{array}{ll}
\max _{L, D} \pi^{c(i)} & =\left(\left(r_{L}^{c}\right)_{i}-r\right) L_{i}^{c(i)}+\left(r(1-\alpha)-\left(r_{D}^{c}\right)_{i}\right) D_{i}^{c(i)} \\
& +\left(\left(r_{L}^{c}\right)_{j}-r\right) L_{j}^{c(i)}+\left(r(1-\alpha)-\left(r_{D}^{c}\right)_{j}\right) D_{j}^{c(i)} \\
& +\theta_{L} r\left(L_{i}^{c(i)}+L_{j}^{c(i)}\right)+\theta_{D} r(1-\alpha)\left(D_{i}^{c(i)}+D_{j}^{c(i)}\right)-C\left(L_{i}^{c(i)}, L_{j}^{c(i)}, D_{i}^{c(i)}, D_{j}^{c(i)}\right) \\
\text { s.t. } & L_{i}^{c(j)}=L_{j}^{c(i)}=0, D_{i}^{c(j)}=D_{j}^{c(i)}=0
\end{array}
$$

where again the constraints ensure that the regional principle holds. Note that we use the same cost function $C(\cdot)$ in (6) and (7). This reflects the stylized fact that cooperative banks (and savings banks) despite being small compared to private commercial banks cooperate in their network and are thus able to produce with the same technology as a large bank. However, this assumption is not crucial for our results.

Maximization with respect to loan volume and solving the first-order condition leads to reaction functions in market $i$

$$
L_{i}^{0}\left(L_{i}^{c(i)}\right)=\frac{1}{2}\left(a-r-\frac{\partial C}{\partial L_{i}^{0}}-b L_{i}^{c(i)}\right)
$$

for the private commercial bank and

$$
L_{i}^{c(i)}\left(L_{i}^{0}\right)=\frac{1}{2}\left(a-r-\frac{\partial C}{\partial L_{i}^{c(i)}}-b L_{i}^{0}+\theta_{L} r\right)
$$

for the cooperative bank, where $\partial C / \partial L_{i}^{k}$ are the marginal operational costs for loans of bank $k$. Note the last term in (9): The higher the output orientation in the cooperative bank's loan business, i.e., the higher $\theta_{L}$, the higher will be its loan volume for a given loan volume of the private commercial bank. 


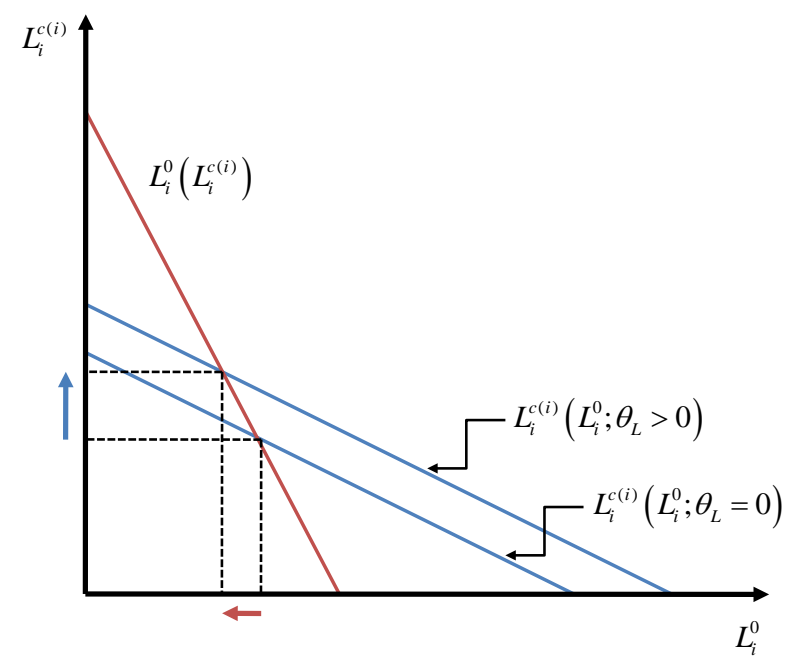

FIGURE 2: BEST-RESPONSE FUNCTIONS IN A LOAN MARKET WITH REGIONAL DEMARCATION

In fact, bank $c$ 's interest in output in addition to profit works like a commitment to more aggressive behavior in the loan market, implying a rightward shift of the cooperative bank's reaction curve. Figure 2 depicts this effect for constant marginal costs and $b=1$. For a $\theta_{L}>0$ bank $c(i)$ sells more loans and bank 0 sells less.

Solving the best-response functions (8) and (9) for the Cournot-Nash equilibrium in loan market $i$ leads to

$$
\begin{aligned}
& L_{i}^{0}=\frac{1}{4-b^{2}}\left[(2-b)(a-r)-2 \frac{\partial C}{\partial L_{i}^{0}}+b \frac{\partial C}{\partial L_{i}^{c(i)}}-b \theta_{L} r\right] \\
& L_{i}^{c(i)}=\frac{1}{4-b^{2}}\left[(2-b)(a-r)-2 \frac{\partial C}{\partial L_{i}^{c(i)}}+b \frac{\partial C}{\partial L_{i}^{0}}+2 \theta_{L} r\right]
\end{aligned}
$$

from which we can calculate the equilibrium interest rates charged as

$$
\begin{aligned}
\left(r_{L}^{0}\right)_{i} & =\frac{1}{4-b^{2}}\left[(2-b) a+\left(2+b-b^{2}\right) r+\left(2-b^{2}\right) \frac{\partial C}{\partial L_{i}^{0}}+b \frac{\partial C}{\partial L_{i}^{c(i)}}-b \theta_{L} r\right] \\
\left(r_{L}^{c(i)}\right)_{i} & =\frac{1}{4-b^{2}}\left[(2-b) a+\left(2+b-b^{2}\right) r+\left(2-b^{2}\right) \frac{\partial C}{\partial L_{i}^{c(i)}}+b \frac{\partial C}{\partial L_{i}^{0}}+\left(b^{2}-2\right) \theta_{L} r\right] .
\end{aligned}
$$

If $b=0$, customers perceive loans of the two banks as completely different, nonsubstitutable products, and both banks produce their monopoly loan volume. Note, however, that even then the cooperative bank will have a loan volume $\theta_{L} r / 2$ above the private commercial bank's loan volume for the benchmark case of identical marginal costs of lending, and it will charge, by the same token, a lower interest rate. For the case of loans being perceived as homogeneous $(b=1)$, bank $c$ 's loan volume will be higher by $\theta_{L} r$. 
In general we find that the loan volume $L_{i}^{c(i)}$ sold by the cooperative bank under regional demarcation is above the volume $L_{i}^{0}$ of the private commercial bank, if and only if

$$
\frac{\partial C}{\partial L_{i}^{c(i)}}-\theta_{L} r<\frac{\partial C}{\partial L_{i}^{0}}
$$

i.e., as long as the difference between the cooperative bank's marginal operational costs in the loan business and its marginal valuation of its non-profit objective is smaller than the marginal costs of the private commercial bank. The fact that it values loan quantity per se makes the cooperative bank more aggressive in the loan market and implies a shift of bestresponse functions and market shares as indicated in Figure 2. Condition (12) can hold even if the cooperative bank has a cost disadvantage. Its commitment to the non-profit objective offsets a competitive advantage of the private commercial bank. Our solution is in line with that of Neumann and Reichel, although they assume that marginal costs of a cooperative or savings bank exceed those of the private commercial bank, if commercial banks are to stay in the market (cf. Neumann \& Reichel, 2006, pp. 255-256).

In our model economies of scale and scope are clearly an issue to be discussed. The marginal operational costs of loans were assumed neither to be constant nor to be identical. For bank 0 they depend also on the level of business in market $j \neq i$. Economies of scale could in principle lead to a cost advantage of bank 0 which operates in both markets, and to a violation of (12). Furthermore, a higher total deposit volume from both markets could lower the marginal cost of lending under economies of scope between the loan business and the deposit business. ${ }^{5}$ Whether or not cooperative or savings banks have higher marginal costs than private commercial banks is, in the end, an empirical question. Cost disadvantages of these non-profit banks could arise from their smaller size or the greater density of their branch networks. However, there are also factors which can compensate such disadvantages or even lead to cost advantages. As mentioned above, both in the savings and the cooperative banking sectors there is large-scale cooperation between banks and via their umbrella organizations, leading effectively to the realization of economies of scale. We should also be aware of the fact that savings and cooperative banks with their regional focus enjoy an informational advantage over private commercial banks, leading to lower lending costs. As for economies of scope, we find it hard to believe that the difference in deposit volumes between bank 0 and bank $c(i)$ can lead to a significant cost advantage of bank 0 in the loan business. Taken together, condition (12) seems to be in good shape. Under normal circumstances we can expect it to hold.

Turning briefly to the interest rates borrowers pay for their loans we find that if (12) holds, the loan rate at the cooperative or savings bank $c(i)$ is lower than the rate at the private commercial bank as long as loans are considered as differentiated products $(b<1)$. Quite

\footnotetext{
${ }^{5}$ A negative cross-derivative between loans and deposits in bank 0's cost function would be sufficient for economies of scope.
} 
naturally, for $b=1$, i.e., the case of homogeneous products, interest rates for loans are identical at both banks.

An analogous analysis can be performed for competition in the deposit market. We arrive at similar conclusions: Cooperative and savings banks in equilibrium have a higher volume of deposits in a market compared to a private commercial bank, if and only if

$$
\frac{\partial C}{\partial D_{i}^{c(i)}}-\theta_{D} r(1-\alpha)<\frac{\partial C}{\partial D_{i}^{0}}
$$

holds. Again the commitment to output reflected in the objective function could even compensate a cost disadvantage of bank $c(i)$. If customers perceive deposits as differentiated products ( $f<1),(13)$ implies that the private commercial bank pays a lower interest on deposits than the cooperative bank. For homogeneous deposits $(f=1)$ interest rates are the same. Hannan and Prager got similar results in their analysis of single-market and multi-market banks in the US, finding that banks offering their products in several markets grant lower deposit rates than banks operating only locally (Hannan \& Prager, 2004, p. 1891).

\subsection{Equilibrium Without Regional Demarcation}

Having analyzed the two banking markets under regional demarcation, we now move on to a different framework where both the commercial bank 0 and the two cooperative banks $c(1)$ and $c(2)$ are allowed to offer their products in both markets. There is no longer regional demarcation preventing bank $c(j)$ from competing in market $i$. Instead, we have the situation depicted in Figure 3.

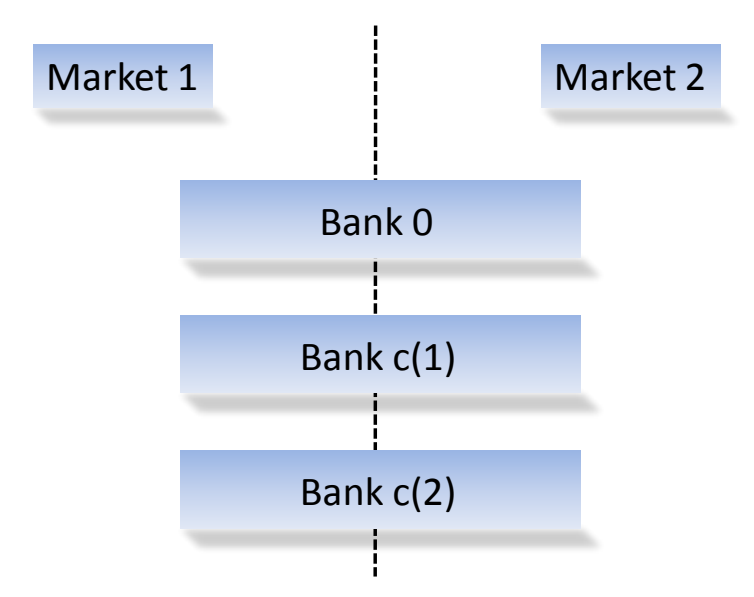

FIGURE 3: BANKING MARKETS WITHOUT REGIONAL DEMARCATION

We first need to aggregate loan demand and deposit supply of the two adjacent markets. Demand and supply conditions (5) are now replaced by 


$$
\begin{aligned}
& r_{L}^{0}=a-\frac{1}{2} L^{0}-\frac{b}{2}\left(L^{c(i)}+L^{c(j)}\right) \quad \text { and } \quad r_{L}^{c}=a-\frac{1}{2}\left(L^{c(i)}+L^{c(j)}\right)-\frac{b}{2} L^{0} \\
& r_{D}^{0}=e+\frac{1}{2} D^{0}+\frac{f}{2}\left(D^{c(i)}+D^{c(j)}\right) \quad \text { and } \quad r_{D}^{c}=e+\frac{1}{2}\left(D^{c(i)}+D^{c(j)}\right)+\frac{f}{2} D^{0} .
\end{aligned}
$$

Customers perceive products of the two cooperative banks $c(i)$ and $c(j)$ as perfect substitutes, i.e., there is only product differentiation between the private commercial bank and the two cooperative banks. Arbitrage prevents the banks to price discriminate between the two markets.

Using (14) to describe demand and supply conditions and dropping the constraint of regional demarcation, the private commercial bank's profit maximization problem implies now for its loan business in both markets

$$
L^{0}\left(L^{c(i)}, L^{c(j)}\right)=a-r-\frac{\partial C}{\partial L^{0}}-\frac{b}{2}\left(L^{c(i)}+L^{c(j)}\right)
$$

For cooperative bank $c(i)$ we get

$$
L^{c(i)}\left(L^{c(j)}, L^{0}\right)=a-r-\frac{\partial C}{\partial L^{c(i)}}-\frac{1}{2} L^{c(j)}-\frac{b}{2} L^{0}+\theta_{L} r
$$

and analogously for bank $c(j)$. Solving for the equilibrium in the aggregate loan market with one profit maximizing and two non-profit banks yields the following loan volumes:

$$
\begin{aligned}
& L^{0}=\frac{1}{3-b^{2}}\left[(3-2 b)(a-r)-3 \frac{\partial C}{\partial L^{0}}+b\left(\frac{\partial C}{\partial L^{c(i)}}+\frac{\partial C}{\partial L^{c(j)}}\right)-2 b \theta_{L} r\right] \\
& L^{c(i)}=\frac{1}{3-b^{2}}\left[(2-b)(a-r)-\left(4-b^{2}\right) \frac{\partial C}{\partial L^{c(i)}}+\left(2-b^{2}\right) \frac{\partial C}{\partial L^{c(j)}}+b \frac{\partial C}{\partial L^{0}}+2 \theta_{L} r\right] \\
& L^{c(j)}=\frac{1}{3-b^{2}}\left[(2-b)(a-r)-\left(4-b^{2}\right) \frac{\partial C}{\partial L^{c(j)}}+\left(2-b^{2}\right) \frac{\partial C}{\partial L^{c(i)}}+b \frac{\partial C}{\partial L^{0}}+2 \theta_{L} r\right] .
\end{aligned}
$$

Since we modeled the two cooperative banks $c(i)$ and $c(j)$ symmetrically, $L^{c(i)}$ will equal $L^{c(j)}$ in equilibrium leading to

$$
L^{c(i)}=\frac{1}{3-b^{2}}\left[(2-b)(a-r)-2 \frac{\partial C}{\partial L^{c(i)}}+b \frac{\partial C}{\partial L^{0}}+2 \theta_{L} r\right] .
$$

From (17) and (14) the equilibrium interest rates $r_{L}^{0}$ and $r_{L}^{c}$ can be calculated.

As before, we are interested in the cooperative banks' share of the market in relation to the private commercial bank's share. It turns out that the two cooperative banks jointly offer a greater loan volume, i.e., $L^{c}=L^{c(i)}+L^{c(j)}>L^{0}$, if and only if 


$$
\frac{\partial C}{\partial L^{c(i)}}-\theta_{L} r<\frac{\partial C}{\partial L^{0}}
$$

This is basically the same condition as (12) which had been derived under regional demarcation. One might suspect that the cooperative bank's marginal costs on the left-hand side are now lower (making the condition even more likely to hold), if there exist economies of scale, because this bank now offers its services in both markets. And if a larger market simplifies the attraction of deposits, economies of scope may further diminish the cooperative bank's marginal loan costs. However, we should be aware of the fact that a cooperative bank not only enjoys a larger market, but also faces more intensified competition due to the presence of the other cooperative bank in its home market.

As for equilibrium interest rates, we again find that cooperative banks charge a loan rate $r_{L}^{c}<r_{L}^{0}$ as long as (19) holds and loans are perceived as differentiated $(b<1)$. When we look at deposits, aggregating deposit supply functions, using arbitrage conditions and solving the maximization problems leads us to an equilibrium in the deposit market, where the two cooperative banks jointly collect more deposits than the private commercial bank, if and only if

$$
\frac{\partial C}{\partial D^{c(i)}}-\theta_{D} r(1-\alpha)<\frac{\partial C}{\partial D^{0}}
$$

and pay a higher interest on deposit as long as deposits are differentiated $(f<1)$.

\subsection{Comparison of the Analysis With AND Without Regional Demarcation}

We are now in a position to compare the equilibrium under regional demarcation to the one without regional demarcation. Recall that we would like to know whether regional demarcation reduces the intensity of competition as the European Commission had suspected. We therefore focus on loan volumes and profit levels. Let $L_{r e g}^{k}$ denote bank $k$ 's total loan volume from one or, if relevant, both markets in the equilibrium under regional demarcation and let $L_{\text {nreg }}^{k}$ denote total loan volume without regional demarcation. Comparing equilibrium values for a cooperative bank $c(i)$, we find that the bank hands out less loans under regional demarcation, i.e., $L_{\text {reg }}^{c(i)}=L_{i}^{c(i)}<L_{\text {nreg }}^{c(i)}$, if

$$
\begin{aligned}
\left(3-b^{2}\right)[ & \left.(2-b)(a-r)-2 \frac{\partial C}{\partial L_{i}^{c(i)}}+b \frac{\partial C}{\partial L_{i}^{0}}+2 \theta_{L} r\right] \\
& <\left(4-b^{2}\right)\left[(2-b)(a-r)-2 \frac{\partial C}{\partial L^{(i)}}+b \frac{\partial C}{\partial L^{0}}+2 \theta_{L} r\right]
\end{aligned}
$$

$3-b^{2}$ is positive and less than $4-b^{2}$. Condition (21) then hinges on the signs and relative magnitudes of the two terms in squared brackets. Both squared brackets are strictly positive, if the cooperative bank sells a strictly positive loan volume both under regional demarcation 
and without regional demarcation. Note that the change in marginal costs between the two regimes matters, since for both bank $c(i)$ and bank 0 on the left-hand side we find the marginal costs related to the loan volume sold in market $i$ only, whereas on the right-hand side the marginal costs relate to the total loan volume sold by a bank in both markets. To fix ideas on a benchmark, let us assume that the marginal costs of lending for bank $c(i)$ remain unchanged, i.e., $\partial C / \partial L_{i}^{c(i)}=\partial C / \partial L^{c(i)}$. For the private commercial bank 0 the analogous assumption $\partial C / \partial L_{i}^{0}=\partial C / \partial L^{0}$ is quite natural, given that this bank serves both markets under both regimes and in a realistic scenario will also be present in a large number of other local markets. Under these assumptions the two squared brackets are identical, and we conclude that the cooperative bank will have a higher loan volume without regional demarcation compared to the regime under regional demarcation.

We still need to develop an intuitive understanding of what will happen, if marginal costs are not identical across regimes. Earlier we argued that cooperative and savings banks with the help of their networks and umbrella organizations already today realize economies of scale. However, if bank $c(i)$ in the regime without regional demarcation offers loans in the adjacent market $j$, it might suffer from informational disadvantages and customers who still need to be convinced to come to bank $c(i)$. This could amount to an increase in the marginal costs of lending, implying $\partial C / \partial L_{i}^{c(i)}<\partial C / \partial L^{c(i)}$. As long as this increase is not too strong, it will not alter our result. If, on the other hand, serving a second market leads to a decrease in the marginal costs of loans at the cooperative bank, our result is strengthened.

Knowing that each cooperative bank extends its loan supply when the regional demarcation principle is abolished, we now look at bank 0 . The private commercial bank will sell a higher loan volume under regional demarcation, i.e., $L_{\text {reg }}^{0}>L_{\text {nreg }}^{0}$, if in the benchmark case of identical marginal costs across regimes considered before

$$
2 b\left(a-r-\frac{\partial C}{\partial L^{c(i)}}+\theta_{L} r\right)-b^{2}\left(a-r-\frac{\partial C}{\partial L^{0}}\right)>0 .
$$

The term in the first bracket is nothing else but two times bank $c(i)$ 's monopoly output in market $i$. By the same token the second bracket equals twice bank 0's monopoly profit in that market. If the marginal costs of both banks were identical, bank $c(i)$ would sell a higher monopoly output than bank 0 as long as it pursues a non-profit objective $\left(\theta_{L}>0\right)$ and (22) would hold. A cost disadvantage of the cooperative bank weakens this result, whereas stronger non-profit orientation and less differentiation strengthen it. If loans are perfectly differentiated $(b=0)$, bank 0 sells the same loan volume under both regimes.

Finally, we are interested in the total loan volume in both markets without regional demarcation compared to a situation with regional demarcation. We know already that cooperative banks will increase loan volumes and the private commercial bank will decrease 
its loan volume once regional demarcation is abolished. Again we assume identical marginal costs across regimes. The expansionary effect at non-profit banks dominates the contractionary effect at the private commercial bank, i.e., $L_{\text {nreg }}>L_{\text {reg }}$, if

$$
(2-b)\left[(2-b)(a-r)-2 \frac{\partial C}{\partial L^{c(i)}}+b \frac{\partial C}{\partial L^{0}}+2 \theta_{L} r\right]>0
$$

The term in squared brackets is the loan volume a cooperative bank sells in the two markets, if there is no regional demarcation. I.e., as long as abolishing regional demarcation does not push the non-profit banks out of the loan markets (which we do not expect given that they increase their loan business once demarcation is abolished), total loan volume will be higher without demarcation.

As for profit levels, similar comparisons show that the private commercial bank's profits from its loan business will decrease under plausible conditions once regional demarcation is abolished. When we look at cooperative banks and evaluate their objective functions (inclusive of the non-profit objective as introduced in (4)), we find that the non-profit banks will benefit, if there is no longer regional demarcation, as long as loan products are sufficiently homogeneous.

To sum up, abolishing the regional demarcation principle leads to an improved supply of loans and to lower interest rates for loans. This conclusion supports the European Commission's qualm about regional demarcation and the proposition that the (self-) restriction to regional markets limits competition and therefore loan supply. Bank customers would be better off without this limiting constraint. But in stark contrast to the claim of some private commercial banks and their lobbyists, this distortion is not beneficial to cooperative or savings banks but favorable for private commercial banks which face less competition. A tradition or regulation which protects savings banks from savings banks and cooperative banks from cooperative banks effectively shields private commercial banks from intensified competition.

\section{EXTENSIONS}

In this section we want to shed some light on the role the parameters $\theta_{L}$ and $\theta_{D}$ play. Recall that these two parameters are the distinctive characteristics of bank $c(i)$ 's objective function. In a first step we compare the situation analyzed before to a world where all banks are private commercial banks. With this comparison we want to show which adjustments are due to market integration when regional demarcation is abolished and which of them refer to the existence of non-profit banks. This will clarify the influence $\theta_{L}$ and $\theta_{D}$ have on the results. Then we introduce different parameters for the different submarkets to reflect the fact that a cooperative bank may treat loyal customers in its home market differently compared to new customers in the adjacent market. 
To investigate competition only between profit maximizing banks, assume that $\theta_{L}$ and $\theta_{D}$ equal zero. We call this situation pure competition while a market where commercial and cooperative banks compete is called mixed. The pure situation with regional demarcation is already depicted in figure 2: in a symmetric equilibrium both commercial banks offer the same amount of loans and deposits if marginal costs are identical. The quantities are smaller than the amounts a non-profit bank would offer. In detail private commercial bank 01 offers the following credit supply, depending on its own marginal costs and those of its competitor 02 :

$$
L_{i}^{01}=\frac{1}{4-b^{2}}\left[(2-b)(a-r)-2 \frac{\partial C}{\partial L_{i}^{01}}+b \frac{\partial C}{\partial L_{i}^{02}}\right]
$$

If both commercial banks are identical, the total loan supply in market $i$ sums up to

$$
L_{i}^{\text {pure }}=\frac{2}{2+b}\left[a-r-\frac{\partial C}{\partial L_{i}^{0}}\right]
$$

This amount is smaller than the amount of loans offered in a mixed market, as long as condition (12) holds. The existence of a non-profit competitor, i.e., a strictly positive value of $\theta_{L}$, then improves the credit supply in separated markets. Condition (13) suggests an analogous conclusion for total deposit supply.

In order to identify the effect the integration of markets has on loan and deposit quantities we next consider an aggregated market where 3 private commercial banks compete. Then bank 01 offers a loan quantity of

$$
L^{01}=\frac{1}{(2-b)(1+b)}\left[(2-b)(a-r)-(2+b) \frac{\partial C}{\partial L^{01}}+b\left(\frac{\partial C}{\partial L^{02}}+\frac{\partial C}{\partial L^{03}}\right)\right] .
$$

Again the three banks serve the market equally if marginal costs are equal. In this case the total loan amount in the integrated market is

$$
L^{\text {pure }}=\frac{3}{1+b}\left[a-b-\frac{\partial C}{\partial L^{0}}\right]
$$

which is less than a mixed oligopoly would offer if the following condition holds:

$$
2(2-b)\left[a-r-\frac{\partial C}{\partial L^{c}}+\theta_{L} r\right]-(3+b)(2-b)\left[a-r-\frac{\partial C}{\partial L^{0}}\right]+2 b(2-b)(a-r)>0 \text {. }
$$

The term in the first squared brackets is the monopoly output of a cooperative bank, whereas the second one displays the monopoly output of a private commercial bank. As mentioned above, we would expect a non-profit bank to offer more, if $\theta_{L}$ is positive and 
therefore (28) to hold. This shows again that credit supply is better in a mixed (integrated) market and $\theta_{L}$ improves market outcomes.

Comparing the situations with and without regional demarcation under pure competition shows that the integration of the adjacent markets leads to a reduction of the loan amount of a single bank due to more intense competition. At the same time the total loan supply in the aggregated market increases due to the additional competitor. This is a standard result from oligopoly theory. In the analysis of mixed markets the outcomes for the commercial bank turn out to be quite similar. When regional demarcation is abolished, the credit supply of the commercial bank decreases while the total loan supply increases. But here the loan quantity the cooperatives offer increases when markets get integrated. Therefore the commercial's loan quantity has to further decrease in order to attain the same increase in total credit supply. This result strengthens the finding that a private commercial bank is shielded from fierce competition by the existence of regional demarcation.

So far each non-profit bank had the same weights $\theta_{L}$ and $\theta_{D}$ for loans and deposits in its objective function, no matter whether it operated in one or two markets. However, when a non-profit bank enters a new market it is not engrained in this region and emotionally related to the new customers living there. This suggests lower values of $\theta_{L}$ and $\theta_{D}$ in the adjacent region which becomes accessible once regional demarcation is lifted. If the nonprofit bank acts like a commercial bank in its non-domestic market, then $\theta_{L}$ and $\theta_{D}$ with respect to this market equal zero. Because of this different treatment of markets we introduce market specific evaluations. We denote the additional marginal value attached in a bank's objective function to loans and deposits with customers of the home market by $\theta_{L}^{H}$ and $\theta_{D}^{H}$, and those related to customers in the adjacent market by $\theta_{L}^{F}$ and $\theta_{D}^{F}$. As long as regional demarcation exists, these new parameters make no difference because non-profit banks are active only in their home markets, i.e., only $\theta_{L}^{H}$ and $\theta_{D}^{H}$ are relevant. When markets are integrated, each cooperative bank deals with customers from its home market and acquires new customers from the adjacent market. A cooperative bank allocates its activities between its traditional home market and the newly accessible market according to the marginal valuations in its objective function. Calculations show that a cooperative bank offers the more loans and takes the more deposits in its initial market, the higher are $\theta_{L}^{H}$ and $\theta_{D}^{H}$. Similarly, it does more business with customers from the adjacent market, the higher are $\theta_{L}^{F}$ and $\theta_{D}^{F}$. The competing banks react with a decrease in quantities on such offensive strategies. The cooperative bank from market 2 enters the other cooperative bank's home market 1 with a loan and deposit quantity decreasing in $\theta_{L}^{H}$ and $\theta_{D}^{H}$. This also has a quantity reducing effect for the private commercial bank. Conversely a high $\theta_{L}^{F}$ and $\theta_{D}^{F}$ decrease the loan and deposit quantities the cooperative bank 1 and the commercial bank offer in market 1. 
In the most realistic and relevant case of $\theta_{L}^{H}>\theta_{L}^{F}>0$, the cooperative bank already established in a market offers more loans to customers in this market than the entering cooperative bank from the adjacent market. Similar to the analysis before, the loan quantity of the established cooperative bank is greater than the one of the private commercial bank, if products are differentiated and the monopoly output of the cooperative bank exceeds that of the private commercial bank. Whether the cooperative bank from the adjacent market enters the market with a greater loan quantity than the commercial bank depends on the magnitude of $\theta_{L}^{F}$ and monopoly outputs.

If a cooperative bank cares only about customers in its traditional market, $\theta_{L}^{F}$ and $\theta_{D}^{F}$ equal zero, and a cooperative bank will act like a commercial bank in the adjacent market once it has the opportunity to serve it. In this case, the cooperative bank offers a higher loan amount compared to its competitors in its initial market and becomes the dominant bank in this market. Therefore the market-specific valuation has a separating effect and mitigates the consequences the abolition of regional demarcation has.

One more scenario which could be examined is the case of $\theta_{D}=0$. It means that a cooperative bank has a non-profit motive only with respect to loans but not with respect to deposits.

\section{CONCLUSION}

In a widely noticed report on retail banking the European Commission in 2007 expressed its qualms about cooperation in the savings banks and cooperative banks sectors of the financial services industries in several member states. From the Commission's point of view this close cooperation may damage effective competition. The report and the ensuing public discussion motivated us to analyze in more detail one specific form of cooperation, the principle of regional demarcation followed among savings banks and cooperative banks in a number of member states. Applying the industrial economics approach to the microeconomics of banking we modeled two adjacent markets, where one private commercial bank serves both markets and initially competes in each market with a savings or cooperative bank focusing on this market. We contrasted this setup under regional demarcation with an alternative one, where each of the savings or cooperative banks is present in both markets, i.e., the private commercial bank faces two competitors in each market. Banks were modeled as traditional financial intermediaries, taking deposits and giving loans. Since savings and cooperative banks typically by statute or by tradition pursue also non-profit objectives, we applied an idea from the theory of non-profit firms and captured these banks' inclination to further social welfare or the economic well-being of members by including loan and deposit volumes in their objective functions. This enabled us to also find out to what extent our results depend on the non-profit orientation of savings and cooperative banks. 
We first of all point out that the non-profit objective makes a savings or cooperative bank more aggressive in quantity competition. This is an insight perfectly in line with many wellknown results from oligopoly theory. As a consequence, savings and cooperative banks provide a higher loan volume (at a lower interest rate) and take more deposits (at a higher interest rate) than the private commercial bank they compete with. This result holds both under regional demarcation and without regional demarcation. The fact that there are banks in the loan and deposit markets which pursue a non-profit objective improves market performance and increases effective competition. When we compare the situation without regional demarcation to the one with regional demarcation, we find that each savings or cooperative bank has a higher loan volume and the private commercial bank has a lower loan volume once regional demarcation is abolished. And, probably most important from the European Commission's point of view, total loan volume will be higher without regional demarcation. The private commercial bank will suffer a reduction of profits, whereas the savings or cooperative banks do better when regional demarcation is eliminated. These results are strengthened when comparing the situation to pure competition of commercial banks.

We therefore conclude that our analysis supports to some extent the European Commission's point: Regional demarcation impairs market performance in banking. However, representatives and lobbyists of private commercial banks are mistaken when they claim that they suffer the fact that savings banks do not compete with savings banks and cooperative banks do not compete with cooperative banks. In fact, private commercial banks are shielded by regional demarcation from the aggressive competition of non-profit banks. And, no matter whether we have regional demarcation or not, savings and cooperative banks improve market performance.

Without doubt our analysis excluded a number of interesting aspects some of which we will address in the future. A first area for further discussion is the specification of the stylized non-profit objective function, in particular the weights attached to volumes of loans and deposits. We already considered a situation where a savings or cooperative bank pursues its non-profit objectives towards customers in its traditional home market more intensively than it does towards new customers once regional demarcation is abolished. We find that a cooperative bank increases the loan supply for its home customers, the higher the weights for its initial home market and the lower the weights for the foreign market. Especially if the non-profit objective is adopted only for the home market, this separates markets, even if regional demarcation is abolished. Our main findings may be mitigated as the cooperative bank from the adjacent market behaves like a private commercial bank. But if weights for the home market are substantial, our results persist. We also expect our results to be robust against different weights for loans and deposits, e.g., expressing the idea that savings and cooperative banks care more about higher loan volumes than about higher deposit volumes. In addition, one could wonder about member compensation in case of a cooperative bank or about a profit motive of the local or regional authority owning a savings bank as part of the 
rather complex bundle of objectives of such a bank under German law. Both aspects would possibly counteract a bank's volume orientation. Furthermore, regional demarcation was exogenously given in our model. In Germany, for example, it is a voluntarily, strategic choice in the cooperative banking sector, and a statutory rule prescribed by the law governing savings banks. One could endogenize the decision for or against regional demarcation by leaving it to the banks themselves to decide whether or not to operate in an adjacent market. Given the wave of mergers the cooperative and savings banking sectors have experienced during recent decades, we could also ask how these mergers affect market performance in a framework with or without regional demarcation. Another aspect of discussion is the choice of decision variables. Despite our conviction that Kreps and Scheinkman's argument applies here, the special circumstances concerning equity (and therefore capacity) in the banking sector make it worthwhile to take a look at price competition, too. We are planning to do this in a next step. Finally, in the tradition of the industrial economics approach to banking, there was no uncertainty in our model. One may wonder how our results will change, if some form of risk is included. The most natural one would be credit risk, and existing literature shows that banks then gather information about their customers to solve asymmetric information problems. In our case, the regional focus of savings and cooperative banks may help them to extract especially soft information about their borrowers and therefore improve contracting. Besides, intuition tells us that regional demarcation prevents savings and cooperative banks from enjoying more diversified loan portfolios (and protects them at the same time from selling loans in markets where they do not properly understand the risks). Whereas including uncertainty in industrial economics models of banks, e.g. to examine capital regulation or credit derivatives, has become more common during the last decade for the cases of perfect competition and monopoly, an analysis of two adjacent oligopoly markets under credit risk still poses a considerable challenge for future research.

\section{REFERENCES}

Bárcena-Ruiz, J. (2007). Endogenous Timing in a Mixes Duopoly: Price Competition. Journal of Economics, vol. 91 , pp. 263-272.

Barros, F., \& Modesto, L. (1999). Portuguese Banking Sector: A Mixed Oligopoly? International Journal of Industrial Organization, vol. 17, pp. 869-886.

Brunner, A., Decressin, J., Hardy, D., \& Kudela, B. (2004). Germany's Three-Pillar Banking System - Cross Country Perspectives in Europe. Washington, D.C.: International Monetary Fund.

Carletti, E., Hakenes, H., \& Schnabel, I. (2005). The Privatization of Italian Savings Banks - A Role Model for Germany? Vierteljahreshefte zur Wirtschaftsforschung, vol. 74, pp. 32-50. 
Cremer, H., Marchand, M., \& Thisse, J.-F. (1989). The Public Firm as an Instrument for Regulating an Oligopolistic Market . Oxford Economic Papers, vol. 41, pp. 283-301.

De Fraja, G., \& Delbono, F. (1989). Alternative Strategies of a Public Enterprise in Oligopoly. Oxford Economic Papers, vol. 41, pp. 302-311.

Dell'Ariccia, G., \& Marquez, R. (2004). Information and bank credit allocation. Journal of Financial Economics, vol. 72 , pp. 185-214.

Drost, F. M., Köhler, P., \& Scheerer, M. (2007, January 31). Sparkassen und Genossen wehren sich. Retrieved March 20, 2009, from Handelsblatt: http://www.handelsblatt.com/unternehmen/banken-versicherungen/sparkassen-undgenossen-wehren-sich;1218279

Engerer, H., \& Schrooten, M. (2004). Erfolgreiche Sparkassenreformen in Europa. Retrieved März 25, 2009, from Wochenbericht des DIW Berlin, 24/04: http://www.diw.de/deutsch/wb_24/04_erfolgreiche_sparkassenreformen_in_europa/3118 2.html

European Commission. (2007). Sector Inquiry under Article 17 of Regulation (EC) No 1/2003 on retail banking. Brussels.

European Commission, Directorate-General for Competition. (2007). Report on the Retail Banking Sector Inquiry. Brussels.

European Parliament. (2008, June 5). European Parliament Resolution of 5 June 2008 on Competition: Sector Inquiry on Retail Banking. Retrieved January 20, 2009, from European Parliament:

http://www.europarl.europa.eu/sides/getDoc.do?type=TA\&language=EN\&reference=P6-TA2008-0260

Freixas, X., \& Rochet, J.-C. (2007). Microeconomics of Banking. Cambridge, MA: MIT Press.

Gehrig, T. (1998). Screening, cross-border banking, and the allocation of credit. Research in Economics, vol. 52 , pp. 387-407.

Hakenes, H., \& Schnabel, I. (2007). Regionale Banken in einer globalisierten Welt. Kredit und Kapital , vol. 40, pp. 351-380.

Hakenes, H., \& Schnabel, I. (2006). The Threat of Capital Drain: A Rationale for Public Banks? Max Planck Institute for Research on Collective Goods, Reprint 2006/11.

Hannan, T., \& Prager, R. (2004). The Competitive Implications of Multimarket Bank Branching. Journal of Banking and Finance, vol. 28, pp. 1889-1914.

Hempell, H. (2002). Testing for Competition Among German Banks. Economic Research Centre of the Deutsche Bundesbank, Discussion Paper 04/02 . 
Kirstein, R., \& Schliephage, E. (2009). Strategic Effects of Regulatory Capital Requirements in Imperfect Banking Competition. mimeo .

Kreps, D., \& Scheinkman, J. (1983). Quantity precommitment and Bertrand competition yield Cournot outcomes. Bell Journal of Economics, vol. 14, pp. 326-337.

Lakdawalla, D., \& Philipson, T. (2006). The Nonprofit Sector and Industry Performance. Journal of Public Economics, vol. 90, pp. 1681-1698.

Lang, G., \& Welzel, P. (1999). Mergers Among German Cooperative Banks. A Panel-based Stochastic Frontier Analysis. Small Business Economics, vol. 13, pp. 273-286.

Lehner, M., \& Schnitzer, M. (2008). Entry of foreign banks and their impact on host countries. Journal of Comparative Economics, vol. 36 , pp. 430-452.

Merrill, W., \& Schneider, N. (1966). Government Firms in Oligopolistic Industries: A Short Run Analysis. Quarterly Journal of Economics, vol. 80, pp. 400-412.

Müller, H. (2005). Fortentwicklung des Sparkassensektors. Zeitschrift für öffentliche und gemeinwirtschaftliche Unternehmen, Band 28, Heft 4 , pp. 327-357.

Neumann, M., \& Reichel, R. (2006). Struktur der deutschen Bankwirtschaft: Das Dreisäulenmodell ist zeitgemäß. Jahrbuch für Wirtschaftswissenschaften, vol. 57, pp. 247272.

Neumann, M., Reichel, R., \& Weigand, J. (2008). Oligopoly Competition with non-profit Firms - The Case of German Banking. mimeo; presented at the University of Augsburg.

Profil. (2008, July). Schlappe für Neelie Kroes. Retrieved March 20, 2009, from Genossenschaftsverband Bayern: http://www.gvbayern.de/main/Artikel/Profil/Dateien/0807_Schlappe_fuer_Neelie_Kroes.pdf

Rees, R. (1984). Public Enterprise Economics (2nd ed. ed.). London: Weinfeld and Nicolson.

Scheerer, M. (2007, January 31). Kroes macht großen Sparkassen Druck. Retrieved March 20, 2009, from Handelsblatt: http://www.handelsblatt.com/unternehmen/bankenversicherungen/kroes-macht-grossen-sparkassen-druck;1218284

Sealey, C. j., \& Lindley, J. (1977). Inputs, Outputs, and a Theory of Production and Cost at Depository Financial Institutions. Journal of Finance, vol. 32, pp. 1251-1266.

Smith, D. (1984). A Theoretic Framework for the Analysis of Credit Union Decision Making. Journal of Finance, vol. 39 , pp. 1155-1168.

Welzel, P. (1996). Gemeinwohlorientierung im Oligopol - Wirkungen einer Berücksichtigung von Konsumenteninteressen. Ludwig-Maximilians-Universität München, Münchener wirtschaftswissenschaftliche Beiträge, Nr. 96-18. 